\title{
PENERAPAN PENDEKATAN CONTEXTUAL TEACHING AND LEARNING (CTL) DALAM UPAYA MENINGKATKAN KREATIVITAS DAN BERPIKIR KRITIS SISWA KELAS X DI SMA NEGERI 3 PADANGSIDIMPUAN POKOK BAHASAN BANGUN RUANG
}

\author{
Oleh: \\ Eka Sartika Pramono \\ Abdul Sattar Daulay
}

\begin{abstract}
Abstrak
Dalam proses pembelajaran metode yang digunakan guru masih monoton sehingga siswa mudah bosan. Pendekatan yang digunakan guru belum tepat yang mengakibatkan siswa belum efektif dalam proses pembelajaran. Sehingga kreativitas dan berpikir kritis belajar matematika siswa masih rendah dan nilai hasi belajar yang diperoleh siswa masih di bawah KKM.

Penelitian ini bertujuan untuk mengetahui sejauh mana penggunaan pendekatan Contekstual Teaching and Learning (CTL) dapat meningkatkan kreativitas dan berpikir kritis belajar matematika siswa di kelas X-9 SMA Negeri 3 Padangsidimpuan. Dalam penelitian ini yang menjadi setting penelitian adalah siswa SMA Negeri 3 Padangsidimpuan dan subjek penelitian adalah kelas X-9 yang berjumlah 36 siswa.

Penelitian ini adalah Penelitian Tindakan Kelas (PTK). Instrumen pengumpulan data yang digunakan adalah observasi siswa yang dilakukan dan didukung oleh tes hasil belajar siswa. Pada penelitian ini teknik pengumpulan data adalah melalui observasi dan didukung oleh tes hasi belajar. Di dalam analisis data observasi ada dua data pokok yaitu proses dan data hasil. Teknik analisis yang digunakan adalah teknik komparasi (membandingkan) yaitu membandingkan kondisi antara siklus pertaman dengan siklus kedua.

Dari hasil penelitian bahwa pada siklus I pertemuan pertama kreativitas dan berpikir kritis belajar matematika siswa masih rendah, kemudian meningkat pada pertemuan kedua yaitu setiap indikator-indikator dari kreativitas dan tes berpikir kritis belajar matematika siswa meningkat. Karena peningkatan kreativitas dan berpikir kritis belajar matematika siswa belum memenuhi dari aspek yang diamati maka dilanjutkan ke siklus II, yaitu pada pertemuan pertama indikator-indikator kreativitas dan tes berpikir kritis siswa meningkat pada pertemuan pertama. Dan mengalami peningkatan pada pertemuan kedua indikator-indikator kreativitas dan tes berpikir kritis sudah memenuhi bahkan melebihi dari aspek yang diamati yaitu $80 \%$. Lalu peningkatan kreativitas dan berpikir kritis didukung oleh peningkatan hasil belajar yang diperoleh siswa dalam setiap siklus. Maka dapat disimpulkan bahwa pendekatan Contekstual Teaching and Learning (CTL) dapat meningkatkan kreativitas dan berpikir kritis matematika siswa kelas X-9 SMA Negeri 3 Padangsidimpuan.
\end{abstract}




\section{A. Pendahuluan}

Matematika merupakan salah satu bidang studi yang menduduki peranan penting dalam dunia pendidikan, karena dengan adanya matematika merupakan salah satu ilmu dasar yang dapat menunjang adanya ilmu-ilmu lain seperti fisika, kimia, computer, dan lain-lain. Hal ini juga di uraikan di dalam buku strategi pembelajaran matematika kontemporer bahwa matematika merupakan ratu ilmu atau sebagai sumber dari ilmu yang lain, karena banyak ilmu-ilmu yang penemuan dan pengembangannya bergantung pada matematika. ${ }^{1}$ Dari kedudukan matematika sebagai ratu ilmu, menggambarkan bahwa matematika merupakan suatu ilmu yang berfungsi untuk melayani ilmu pengetahuan. Dengan kata lain, matematika tumbuh dan berkembang untuk dirinya sendiri sebagai suatu ilmu, juga untuk melayani kebutuhan ilmu pengetahuan dalam pengembangannya dan operasionalnya.

Kreativitas merupakan bahagian dari matematika dan juga sangat penting dalam kehidupan sehari-hari. Hampir semua manusia berhubungan dengan proses kreaivitas, yang dikembangkan melalui penemuan-penemuan baru. Kreativitas juga semacam cara-cara berpikir tertentu dalam merancang sesuatu untuk menjadi lengkap dan baru sehingga dinilai lebih baik menarik bagi orang yang mengamatinya. Defenisi mengenai produk kreativitas menekankan bahwa apa yang dihasilkan dari proses kreativitas adalah sesuatu yang baru, orisinil dan bermakana.

Pada proses pembelajaran matematika, kemampuan siswa dalam memecahkan masalah, memproses dan menemukan sesuatu yang baru; berupa pengetahuan dan keterampilan juga tidak terlepas dari kemampuan siswa dalam berpikir, terutama berpikir kritis. Hal ini menunjukkan perlunya seorang siswa memiliki kemampuan tersebut. Kemampuan berpikir kritis seseorang dalam suatu bidang studi tidak dapat terlepas dari pemahamannya terhadap materi matematika. Seseorang tak mungkin dapat berpikir kritis dalam suatu bidang studi tertentu tanpa pengetahuan mengenai isi dan teori bidang studi tersebut. Dengan demikian

\footnotetext{
${ }^{1}$ Erman Suherman, Strategi Pembelajaran Matematika Kontemporer (JICA: UPI, 2001), hlm. 29.
} 
agar siswa dapat berpikir kritis dalam matematika, maka dia harus memahami matematika dengan baik.

Untuk itu diperlukan suatu pendekatan baru dimana teori atau konsep matematika dikaitkan dengan kehidupan nyata siswa agar pembelajaran lebih bermakna dan pemahamnnya terhadap suatu materi dapat meningkatkan kreativitas dan berpikir kritis siswa.

Berkaitan dengan kepentingan siswa di atas, penulis menemukan masalah di lokasi penelitian dari hasil observasi dan wawancara dengan guru bidang studi matematika dan ia mengatakan bahwa nilai matematika masih banyak di bawah nilai KKM yaitu nilai 5 sementara nilai KKM untuk matematika adalah 7, ini menggambarkan bahwa masih rendah pemahaman siswa terhadap pelajaran matematika, dan hal ini jelas mencerminkan tingkat kreativitas siswa sangat rendah dan belum berkembangnya kemampuan berpikir kritis siswa.

Dalam hal ini guru sangat berperan dalam keberhasilan proses belajar mengajar untuk mencapai tujuan pendidikan. Guru dituntut melakukan berbagai kegiatan untuk menunjang keberhasilan siswa dalam setiap materi pelajaran yang diajarkan, maka diperlukan adanya perubahan cara mengajar guru dari penggunaan cara mengajar yang konvensional dengan menggunakan pendekatan pembelajaran yang mengarah ke kehidupan sehari-hari agar lebih meningkatkan kreativitas dan berpikir kritis siswa.

Pendekatan kontekstual adalah konsep belajar yang membantu guru mengaitkan antara materi yang diajarkannya dengan situasi dunia nyata siswa dan mendorong siswa membuat hubungan antara pengetahuan yang dimilikinya dengan penerapannya dalam kehidupan mereka sehari-hari. ${ }^{2}$

Pendekatan Contextual Teaching and Learning (CTL) sangatlah baik untuk meningkatkan kreativitas dan berpikir kritis siswa. Dengan berpikir kritis dan kreativitas maka siswa didorong untuk belajar sebagian besar melalui

${ }^{2}$ Siti Halimah, Strategi Pembelajaran (Bandung: Cipta Pusaka Media Perintis, 2008), hlm. 121 
keterlibatan aktif mereka sendiri dengan konsep-konsep, dan guru mendorong siswa untuk memiliki pengalaman dan melakukan percobaan yang memungkinkan mereka menemukan prinsip-prinsip untuk mereka sendiri, khususnya pada materi bangun ruang.

\section{Tinjauan Pustaka}

\section{Pendekatan Contextual Teaching and Learning (CTL)}

Pendekatan pembelajaran CTL merupakan rancangan pembelajaran yang dibangun atas dasar asumsi bahwa knowledge is constructed by human. Jadi dalam hal ini fungsi dan peranan guru hanya sebagai mediator dan siswa lebih proaktif untuk merumuskan sendiri tentang fenomena yang berkaitan dengan fokus kajian secara kontekstual bukan tekstual. ${ }^{3}$

Berdasarkan uraian di atas, dapat dikatakan bahwasanya penggunaan strategi CTL akan membantu guru mengaitkan antara materi yang diajarkannya dengan situasi dunia nyata siswa dan mendorong siswa membuat hubungan antara pengetahuan yang dimilikinya dengan penerapannya dalam kehidupan mereka sebagai anggota masyarakat.

Pembelajaran CTL pada awalnya dikembangkan oleh John Dewey dari pengalaman pembelajaran tradisionalnya. Pada tahun 1918 Dewey merumuskan kurikulum dan metodologi pembelajaran yang berkaitan dengan pengalaman dan minat siswa. Siswa akan belajar dengan baik jika yang dipelajarinya terkait dengan pengetahuan dan kegiatan yang telah diketahuinya dan terjadi di sekelilingnya. Pembelajaran CTL adalah konsep belajar yang membantu guru mengaitkan antara materi pembelajaran yang diajarkan dengan situasi dunia nyata siswa dan mendorong siswa membuat hubungan antara pengetahuan yang dimilikinya dengan penerapannya dalam kehidupan mereka sehari-hari. Dengan

\footnotetext{
${ }^{3}$ Trianto, Mendesain Model Pembelajaran Inovatif-Progresif Konsep, Landasan dan Implementasinya pada Kurikulum Tingkat Satuan Pendidikan (KTSP) (Jakarta: Kencana, 2010), hlm. 104.
} 
demikian pendekatan CTL mengutamakan pada pengetahuan dan pengalaman atau dunia nyata (real world learning), berpikir tingkat tinggi, berpusat pada siswa, siswa aktif, kritis, kreatif, memecahkan masalah, siswa belajar menyenangkan, mengasyikkan, tidak membosankan (joyfull and quantum learning) dan menggunakan berbagai sumber belajar. ${ }^{4}$

Dengan demikian pendekatan CTL merupakan pendekatan pembelajaran yang mendorong agar siswa dapat menemukan hubungan antara materi yang dipelajari dengan situasi kehidupan nyata, artinya siswa dituntut untuk dapat menangkap hubungan antara pengalaman belajar di sekolah dengan kehidupan nyata. Hal ini sangat penting, sebab dengan dapat mengorelasikan materi yang ditemukan dengan kehidupan nyata. bukan saja bagi siswa materi itu akan bermakna secara fungsional, akan tetapi materi yang dipelajarinya akan tertanam erat dalam memori siswa, sehingga tidak akan mudah dilupakan.

Kegiatan pembelajaran kontekstual (CTL) diharapkan dapat meningkatkan hasil belajar yang berkualitas, lebih mendorong timbulnya kreativitas dan produktivitas serta efisiensi dan efektivitasnya yang lebih menjanjikan. Mengapa hasil belajar meningkat, karena dalam pembelajaran yang kontekstual dipergunakan semua alat indra secara serentak sehingga kegiatan pembelajaran menjadi lebih aktual, konkret, realistik, nyata, menyenangkan dan bermakna.

Pendekatan ini melibatkan tujuh komponen utama pembelajaran produktif, yaitu: Konstruktivisme (Constructivism), proses menemukan (Inquiry), bertanya (Questioning), masyarakat belajar (Learning Community), pemodelan (Modelling), refleksi (Reflection), dan penilaian autentik (Authentic Assessment). ${ }^{5}$

\section{Tinjauan Tentang Kreativitas}

Kreativitas adalah kemampuan untuk membuat kombinasi baru, berdasarkan data, informasi, atau unsur-unsur yang ada. Biasanya, orang mengartikan kreativitas sebagai daya cipta, sebagai kemampuan untuk

${ }^{4}$ Sumiati dan Asra, Op. Cit., hlm. 14.

${ }^{5}$ lbid., hlm. 108 
menciptakan hal-hal baru. Sesungguhnya apa yang diciptakan itu tidak prlu halhal yang baru sama sekali, tetapi merupakan gabungan dari hal-hal yang sudah ada sebelumnya. Yang dimaksudkan dengan data, informasi, atau unsur-unsur yang ada, dalam arti sudah ada sebelumnya, adalah semua pengalaman yang diperoleh seorang selama hidupnya. Gagasan-gagasan yang kreatif, hasil karya yang kreatif tidak muncul begitu saja. Untuk dapat menciptakan sesuatu yang bermakna dibutuhkan persiapan. Masa seorang anak duduk di bangku sekolah termasuk masa persiapan, karena pendidikan mempersiapkan seseorang agar dapat memecahkan masalah-masalah. ${ }^{6}$

Secara operasional kreativitas dapat dirumuskan sebagai kemampuan yang mencerminkan kelancaran, keluwesan (fleksibilitas), dan orosinilitas dalam berpikir, serta kemampuan untuk mengelaborasi (mengembangkan, memperkaya, memperinci) suatu gagasan.

Kreativitas adalah aspek lain menghadapi kebaruan. Kreativitas didefenisikan secara tradisional sebagai sesuatu yang baru, baik dan tepat bagi tugas. Kreativitas merupakan bahagian dari keadaan jiwa seorang anak manusia. Menurut Breckenridge dan Vincent kemampuan kreativitas yaitu "creative ability is usually regarded as a special talent or aptitude which manifest it self late in adolescence or in adulthood and some what exclusively among young people and adults who are not quite normal in other respect". Di sini dipahami kemampuan kreatif merupakan bakat khusus atau bakat yang nyata di akhir usia adolesen atau dewasa dan beberapa kekhususan dimiliki diantara anak muda atau dewasa yang mana muncul tidak begitu normal di banding yang lain. ${ }^{7}$

${ }^{6}$ S. C. Utami Munandar, Mengembangkan Bakat Dan Kreativitas Anak Sekolah (Jakarta: PT. Gramedia Widiasarana Indonesia, 1992), hlm 47.

${ }^{7}$ Syafaruddin dan Irwan, Manajemen Pembelajaran (Ciputat: PT. Ciputat Press, 2005), hlm 17. 


\section{B. Metode Penelitian}

\section{Tempat dan Waktu Penelitian}

Peneliti akan melaksanakan penelitian di SMA Negeri 3 Padangsidimpuan Jln. Perintis Kemerdekaan No. 56 Padangsidimpuan Selatan. Penelitian ini dimulai pada tanggal 21 Maret sampai dengan selesai yaitu pada tanggal 4 April 2014.

\section{Jenis Penelitian}

Dalam penelitian ini, desain penelitian yang digunakan adalah Penelitian Tindakan Kelas (PTK) atau Classroom Action Research yang dilakukan secara kolaboratif antara guru mata pelajaran dengan peneliti. Dilihat dari namanya sudah menunjukkan isi yang terkandung di dalamnya, yaitu sebuah kegiatan penelitian yang dilakukan di kelas.

\section{Subjek Penelitian}

Yang menjadi subjek penelitian ini adalah siswa SMA Negeri 3 Padangsidimpuan Kelas X-9 yaitu 1 kelas yang berjumlah 36 orang siswa.

\section{Instrumen Penelitian}

Instrumen pengumpulan data yang penulis lakukan dalam penelitian ini adalah lembar aktivitas siswa,lembar observasi, catatan lapangan dan tes.

\section{Teknik Analisis Data}

Untuk menganalisis data yang telah terkumpul dalam penelitian ini akan dianalisis berupa pengelompokan dan pengkategorian data yang sesuai dengan aspek-aspek yang ditentukan, dalam hal ini peneliti akan menggunakan analisis data statistik yang meliputi : Analisis Data Kuantitatif dan Kualitatif.

\section{Hasil Pembahasan Penelitian}

Berdasarkan hasil data yang diperoleh pada siklus I dan II , maka peneliti melakukan analisis data dengan menggunakan statistik data sederhana yaitu dengan melihat rata-rata tes kemampuan berpikir kritis matematika siswa pada 
setiap siklus untuk melihat sejauh mana peningkatan kemampuan berpikir kritis matematika siswa. Data yang diperoleh pada setiap pertemuan dan dalam setiap siklus terdiri dari hasil tes kemampuan berpikir kritis matematika siswa dan hasil observasi untuk melihat kemampuan kreativitas matematika siswa secara lisan. Setiap data yang diperoleh akan dianalisis sesuai dengan jenis data yang dimaksud. Berikut dijabarkan analisis data untuk setiap data yang diperoleh :

\section{Hasil Tes Kemampuan Berpikir kritis Matematika Siklus I dan Siklus II}

Tes yang dilakukan pada setiap akhir siklus pembelajaran dalam penelitian ini berfungsi untuk melihat sejauh mana peningkatan kemampuan berpikir kritis matematika siswa secara tertulis. Tes berpikir kritis matematika yang diujikan berbentuk soal essay test yang terdiri dari 10 soal yang disusun berdasarkan indikator kemampuan berpikir kritis matematika siswa. Data hasil tes kemampuan berpikir kritis matematika pada tes awal, siklus I dan siklus II disajikan pada Lampiran III pada skripsi ini.

Berdasarkan pada hasil tes diperoleh bahwa penggunaan pendekatan Contextual Teaching and Learning (CTL) dapat meningkatkan kemampuan berpikir kritis matematika siswa pada materi bangun ruang. Hal ini dapat dilihat berdasarkan rata-rata hasil tes kemampuan berpikir kritis matematika dan persentase ketuntasan belajar siswa yang semakin meningkat pada setiap siklusnya. Hal ini dapat dilihat berdasarkan tabel dibawah ini :

Tabel 19

Peningkatan Tes Kemampuan Berpikir Kritis Matematika Siswa

\begin{tabular}{|l|c|c|c|}
\hline \multicolumn{1}{|c|}{ Pelaksanaan } & Rata-Rata Kelas & $\begin{array}{c}\text { Jumlah Siswa } \\
\text { yang Tuntas }\end{array}$ & $\begin{array}{c}\text { Persentase } \\
\text { Ketuntasan } \\
\text { Belajar }\end{array}$ \\
\hline Tes Awal & 64,44 & 11 & $30,55 \%$ \\
\hline Tes Akhir Siklus I & 74,58 & 21 & $58,33 \%$ \\
\hline Tes Akhir Siklus II & 81,25 & 31 & $86,11 \%$ \\
\hline
\end{tabular}


Berikut diagram peningkatan kemampuan komunikasi matematika siswa berdasarkan tes yang dilakukan pada setiap siklusnya:

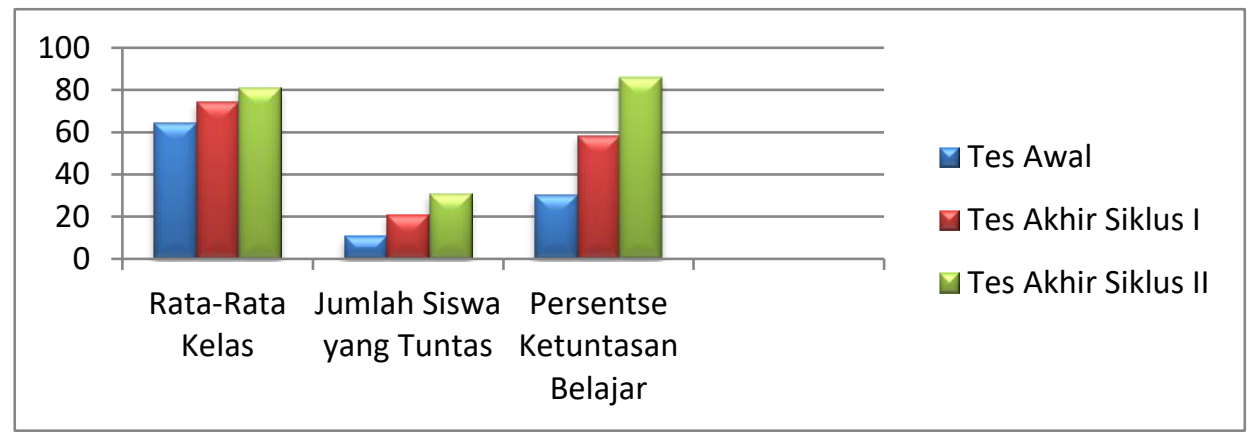

\section{Gambar 3}

\section{Diagram Peningkatan Tes Kemampuan Berpikir Kritis Matematika}

\section{Hasil Observasi Kemampuan Kreativitas Matematika pada Siklus I dan Siklus II}

Observasi kemampuan kreativitas matematika pada skripsi ini dilakukan untuk melihat sejauh mana dorongan rasa ingin tahu siswa, kemampuan siswa dalam mengajukan pertanyaan dengan baik, dapat memberikan gagasan atau usulan terhadap suatu masalah, brani dalam menyatakan pendapat, memiliki pendapat sendiri, daya imajinasi kuat, mampu bekerja sendiri, serta kemampuan mengembangkan atau merinci suatu gagasan secara lisan. Observasi ini dilakukan pada setiap proses pembelajaran yang terjadi pada setiap siklusnya. Kegiatan yang diobservasi disini meliputi :

a. Kemampuan mengekspresikan rasa ingin tahu matematis melalui lisan, dan bebas menyatakan pendapat baik dengan cara mendemonstrasikannya serta menggambarkannya secara visual.

b. Kemampuan mengembangkan atau merinci gagasan matematis secara lisan, maupun dalam bentuk visual lainnya yang dikerjakan melalui hasil pekerjaan sendiri dan melalui imajinasi yang kuat.

c. Kemampuan dalam menggunakan istilah-istilah, notasi-notasi matematika dan struktur-strukturnya untuk menyajikan ide-ide baik dalam mengajukan pertanyaan dengan baik serta mampu menggambarkan hubungan-hubungan dengan model-model situasi dalam gagasan atau usulan terhadap masalah. 
Berikut tabel peningkatan kemampuan kreativitas matematika siswa berdasar hasil observasi yang dilakukan :

Tabel 20

Peningkatan Kemampuan Krativitas Matematika pada Siklus I dan Siklus II Berdasarkan Hasil Observasi

\begin{tabular}{|c|c|c|c|c|c|c|c|c|c|}
\hline \multirow{2}{*}{\multicolumn{2}{|c|}{ Pelaksanaan }} & \multicolumn{8}{|c|}{ Indikator } \\
\hline & & \multirow{2}{*}{$\begin{array}{l}1 \\
-\end{array}$} & \multirow{2}{*}{$\begin{array}{l}2 \\
-\end{array}$} & \multirow{2}{*}{$\begin{array}{l}3 \\
-\end{array}$} & \multirow{2}{*}{$\begin{array}{l}4 \\
-\end{array}$} & \multirow{2}{*}{$\begin{array}{l}5 \\
-\end{array}$} & \multirow{2}{*}{$\begin{array}{l}6 \\
-\end{array}$} & \multirow{2}{*}{$\begin{array}{l}7 \\
-\end{array}$} & \multirow{2}{*}{$\begin{array}{l}8 \\
-\end{array}$} \\
\hline $\begin{array}{l}\text { Observa } \\
\text { si Awal }\end{array}$ & - & & & & & & & & \\
\hline \multirow{2}{*}{ Siklus I } & $\begin{array}{c}\text { Pertemuan } \\
1\end{array}$ & $36 \%$ & $25 \%$ & $19 \%$ & $47 \%$ & $27 \%$ & $25 \%$ & $30 \%$ & $30 \%$ \\
\hline & $\begin{array}{c}\text { Pertemuan } \\
2\end{array}$ & $47 \%$ & $41 \%$ & $30 \%$ & $58 \%$ & $36 \%$ & $41 \%$ & $58 \%$ & $52 \%$ \\
\hline \multirow{2}{*}{ Siklus II } & $\begin{array}{c}\text { Pertemuan } \\
1\end{array}$ & $58 \%$ & $52 \%$ & $47 \%$ & $75 \%$ & $50 \%$ & $55 \%$ & $75 \%$ & $63 \%$ \\
\hline & $\begin{array}{c}\text { Pertemuan } \\
2\end{array}$ & $86 \%$ & $97 \%$ & $89 \%$ & $91 \%$ & $80 \%$ & $80 \%$ & $94 \%$ & $83 \%$ \\
\hline
\end{tabular}

Berikut diagram peningkatan kemampuan kreativitas matematika siswa berdasarkan tes yang dilakukan pada setiap siklusnya :

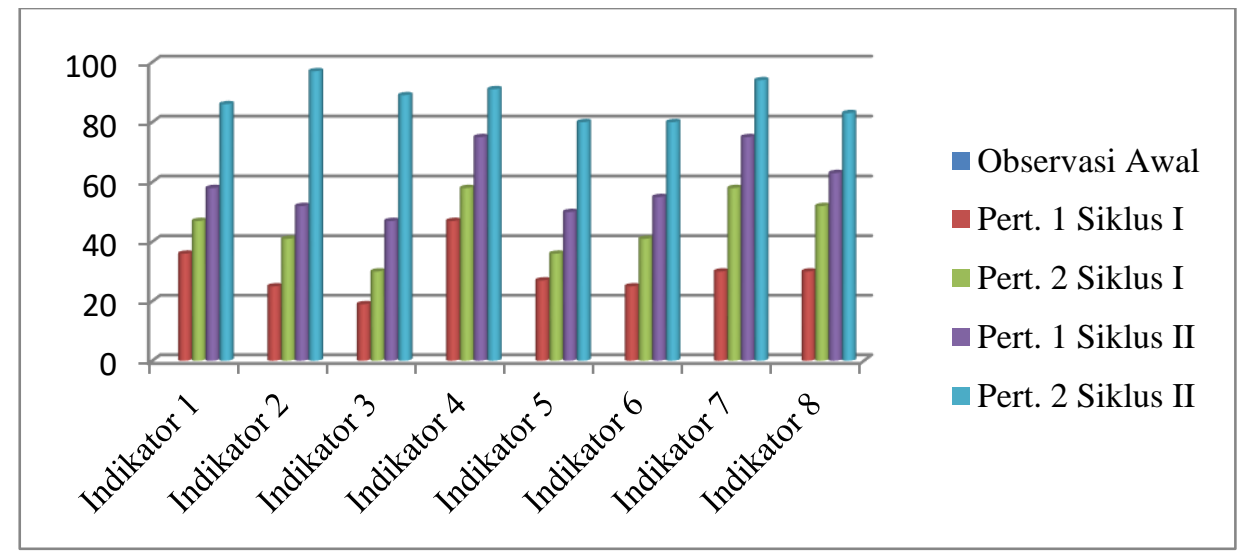

Gambar 4

Diagram Peningkatan Kemampuan Kreativitas Matematika Siswa Berdasarkan Hasil Observasi 
Dengan demikian, berdasarkan diagram peningkatan kemampuan kreativtas dan berpikir kritis matematika berdasarkan tes (Gambar 1) maupun berdasarkan hasil observasi (Gambar 2) terlihat bahwa jumlah siswa yang telah berhasil meningkatkan kemampuan kreativitas dan berpikir kritis matematika telah melebihi $80 \%$ dari jumlah siswa keseluruhan. Dengan demikian, hipotesis tindakan telah berhasil tercapai yaitu penerapan pendekatan Contextual teaching and Learning (CTL) dapat meningkatkan kemampuan kreativitas dan berpikir kritis matematika siswa di kelas X-9 SMA Negeri 3 Padangsidimpuan.

\section{Penutup}

1. Kesimpulan

Dari hasil penelitian yang telah dilakukan dapat disimpulkan bahwa hasil penelitian ini menunjukkan adanya peningkatan kreativitas dan berpikir kritis belajar matematika siswa melalui pendekatan Contekstual Teaching and Learning (CTL) di kelas X-9 SMA Negeri 3 Padangsidimpuan. Hal ini dapat dilihat dari peningkatan rata-rata hasil tes kemampuan berpikir kritis siswa yaitu 64,44 pada tes awal meningkat menjadi 74,58 pada tes akhir siklus I dan pada tes akhir siklus II rata-rata hasil tes kemampuan berpikir kritis matematika siswa mencapai 81,25.

Sementara itu, persentase ketuntasan belajar siswa juga semakin meningkat, hal ini terlihat dari peningkatan jumlah siswa yang mencapai KKM yaitu pada tes awal jumlah siswa yang tuntas adalah 11 siswa atau 30,55 \% dari 36 siswa, pada siklus I siswa yang tuntas ada 21 siswa atau 58,33\% dari 36 siswa dan pada siklus II jumlah siswa yang tuntas mencapai 81,25\% sebanyak 31 dari 36 siswa yang ada.

Selanjutnya, berdasarkan hasil observasi kemampuan kreativitas matematika siswa yaitu pada siklus I pertemuan pertama, indikator-indikator kreativitas belajar matematika siswa di peroleh setiap pertemuan, tetapi belum memenuhi aspek yang di amati yaitu $80 \%$. Lalu indikator-indikator kreativitas belajar matematika pada siklus II setiap pertemuannya juga mengalami peningkatan, hingga pada siklus II pertemuan kedua memenuhi aspek yang di amati yaitu $80 \%$. Karena kreativitas dan berpikir kritis matematika siswa sudah meningkat dalam setiap indikator kreativivitas dan berpikr kritis serta telah 
memenuhi dari aspek yang ditentukan yaitu $80 \%$, maka penelitian ini telah dapat dihentikan

2. Saran

Berdasarkan pada kesimpulan dari penelitian ini, peneliti memiliki beberapa saran yang perlu dikembangkan, yaitu :

1. Kepada guru, pembelajaran dengan menggunakan pendekatan Contekstual Teaching and Learning (CTL) dapat meningkatkan kualitas pembelajaran matematika dan juga mengatasi kesulitan siswa dalam belajar. Maka guru dapat menggunakan pendekatan pembelajaran ini sebagai alternatif dalam memilih model pembelajaran.

2. Bagi siswa, dengan penerapan pendekatan Contekstual Teaching and Learning (CTL) dalam pembelajaran diharapkan agar lebih aktif dalam setiap pembelajaran yang dilakukan.

3. Kepada kepala sekolah, agar lebih memperhatikan kinerja para guru dan memperhatikan proses belajar mengajar di lingkungan sekolah dan mendukung metode dan pendekatan pembelajaran yang digunakan guru.

4. Kepada orang tua hendaknya memberika dorongan kepada siswa agar lebih giat belajar di rumah sehingga hasil belajar yang di peroleh siswa semakin meningkat.

\section{DAFTAR PUSTAKA}

Achmad Arief, "Memahami Berpikir Kritis" 2007, http://researchengines.com/1007arief3,html.

Aisyah Siti, "Pendekatan Kontekstual (Contextual Teaching and Learning) untuk Meningkatkan Hasil Belajar Siswa pada Pokok Bahasan Keliling dan Luas Lingkaran di Kelas VIII MTS Al-Washliyah Tembung Tahun ajaran 2009/2010” Skripsi, IAIN Medan, 2009.

Ali Mohammad dan Mohammad asrori, Psikologi Remaja Perkembangan Peserta Didik Jakarta: PT. Bumi Aksara, 2004.

Arifin, Zainal. Evaluasi Instruksional Bandung: PT Remaja Rosdakarya, 1991. 
Arikunto, Suharsimi. Prosedur Penelitian Suatu Pendekatan Praktik Jakarta: PT Rineka Cipta, 2006.

Asrul dan Amiruddin Siahaan (ed), Panduan Penulisan Skripsi Mahasiswa Peningkatan Kualifikasi Guru MI dan PAI melalui Program Dual Mode System (Medan: Kementrian Agama IAIN Sumatra Utara, 2010.

Djamarah, Syaiful Bahri dan Aswan Zain. Strategi Belajar Mengajar Jakarta: Rineka Cipta, 2006.

Djumransjah. Pengantar Filsafat Pendidikan Malang: Bayumedia Publishing, 2004.

Fisher Alec, Berpikir Kritis Sebuah Pengantar Jakarta: Erlangga, 2009.

Hayat Saepul Deny, Pembelajaran PAI Melalui Pendekatan Kontekstual http://dsh2.wordpress.com, diakses pada tanggal 12 Maret 2011.

http://eko 13. Wordpress. Com /2008/03/16/ciri-ciri dan factor yang mempengaruhi kreativitas/.

Kunandar. Guru Profesional Jakarta: PT. Raja Grafindo Persada, 2007.

Martini. Pembelajaran Standar Proses Berkarakter Jakarta: Prenada, 2011.

Utami Munandar, Mengembangkan Bakat Dan Kreativitas Anak Sekolah Jakarta: PT. Gramedia Widiasarana Indonesia, 1992.

Salim. Peter dan Yenny Salim. Kamus Bahasa Indonesia Kontemporer Jakarta: Modern English Press, 1991.

Setiawan, Conny. Pendekatan Keterampilan Proses Jakarta: PT Gramedia, 1992.

Soemanto Wasty, Psikologi Pendidikan Jakarta: PT. Rineka Cipta, 2003.

Sumiati dan Asra. Metode Pembelajaran Bandung: CV. Wacana Prima, 2008.

Suryadipura Prayana, Alam Pikiran Semarang: Bumi Aksara, 2005.

Syafaruddin dan Irwan, Manajemen Pembelajaran Ciputat: PT. Ciputat Press, 2005.

Tafsir, Ahmad. Ilmu Pendidikan dalam Perspektif Islam Bandung: PT Remaja Rosdakarya, 2005. 
Tim Citra Umbara, Undang-Undang R.I Nomor. 20 Tahun 2003 Tentang SISDIKNAS dan Peraturan Pemerintahan R.I. Tahun 2010 Tentang Penyelenggaraan Pendidikan Serta Wajib Belajar Bandung: Citra Umbara, 2012.

Tim Citra Umbara, Undang-Undang RI Nomor 14 Tahun 2005 dan Peraturan Menteri Pendidikan Nasional RI Nomor 11 Tahun 2011 Tentang Guru dan Dosen Bandung: Citra Umbara, 2012.

Tohirin. Psikologi Pembelajaran Pendidikan Agama Islam Jakarta: RajaGrafindo Persada, 2005.

Trianto. Mendesain Model Pembelajaran Inovatif-Progresif Konsep, Landasan dan Implementasinya Pada Kurikulum Tingkat Satuan Pendidikan (KTSP) Jakarta: Kencana, 2010.

Undang-undang Dasar Tahun 1945 Amandemen I, II, III, IV Jakarta: Pustaka Sandro Jaya, t. th.

Wahidah Ida, "Pengaruh Pendekatan Kontekstual Dalam Pembelajaran

Matematika

Pokok Bahasan Sistem Persamaan Linear

Terhadap Kemampuan Berpikir Kritis Siswa Kelas X Mas Darul Ikhlas

Panyabungan Tahun Ajaran 2011/2012” Skripsi, STAIN

Padangsidimpuan, 2008. 